i andre nakkeslengsmaterialer. En uriktighet blir ikke mer riktig ved å gjentas.

I aktuelle Høyesterettsdom har vi påvist mange, litt uriktige påstander. Små hver for seg, men alle har gått i den skadedes disfavør.

Stovner har fra første stund fremhevet at han ikke var interessert i å diskutere våre synspunkter, som angivelig var for «private», hva han nå måtte mene med det. Han ville derfor benytte denne anledningen til å propagandere for Litauen-studien, samt fremme egne synspunkter. Utspillene har stort sett vært hans. Vi har bare svart.

Det kan vel hende at det med tiden vil vise seg at nakkesleng per se ikke leder til særlige organiske plager, men Litauen-studiene bidrar ikke til slik kunnskap. Vi føler nå at det ikke er riktig å oppta mer spalteplass siden ingen endring i Stovners grunnholdning har funnet sted, og ingen nye synspunkter synes å fremkomme.

\section{Ottar Sjaastad}

ellhed@online.no

Johan Petter Hesselberg

Ottar Sjaastad (f. 1928) er dr.med., spesialist i nevrologi, pensjonert overlege og professor.

Ingen oppgitte interessekonflikter.

Johan Petter Hesselberg (f. 1932) er spesialist i nevrologi og pensjonert overlege.

Ingen oppgitte interessekonflikter.

\section{Re: Klimakamp er helsearbeid}

I en kronikk i Tidsskriftet nr 16/2014 skriver professor emeritus Gunnar Kvåle at leger har ansvar for å bidra til å hindre klimaendringer med meget alvorlige konsekvenser for liv og helse (1). Han nevner energisparing og overgang fra fossilt brennstoff til mer bærekraftige energiformer som viktige tiltak.

Dette er gode poenger, og noen av de viktige politiske grepene som er nødvendig. Hver og en av oss kan imidlertid også gjøre en viktig innsats - både gjennom vår yrkesutøvelse som leger og egen livsstil. Ved å dreie i retning av et mer plantebasert kosthold, med redusert inntak av kjøtt og animalske produkter, kan vi bidra til betydelig reduksjon i klimagassutslipp og i tillegg spare energi, vann- og matressurser. Slike kostendringer kan samtidig forebygge en stor andel av livsstilssykdommene og tidlige dødsfall.

I følge FNs klimapanel står produksjon av kjøtt og andre matvarer fra dyreriket for hele $18 \%$ av verdens klimagassutslipp (2). Produksjon av kraftfôr til husdyr legger beslag på en stor andel av verdens mest knappe ressurs - rent vann, samt næringsrike matvarer som soya, korn og mais $(3,4)$. For å produsere ett kilo kjøtt bruker norsk industrilandbruk en stor mengde importert kraftftôr som kunne blitt brukt som mat både i Norge og i andre land $\mathrm{i}$ tillegg til at mange områder som kunne blitt brukt til annen matproduksjon blir brukt til beitemark.

Kan vi mennesker leve av et plantebasert kosthold? Helsemyndigheter og de fleste forskere over hele verden har for lengst anerkjent at et kosthold bestående utelukkende av plantebasert (vegansk) kost beriket med vitamin B12 er fullverdig og innebærer en rekke helsefordeler (5). Amerikansk forening for ernæringsfysiologer, Academy of Nutrition and Dietetics, har for eksempel uttalt: «It is the position of the American Dietetic Association that appropriately planned vegetarian diets, including total vegetarian or vegan diets, are healthful, nutritionally adequate, and may provide health benefits in the prevention and treatment of certain diseases. Wellplanned vegetarian diets are appropriate for individuals during all stages of the life cycle, including pregnancy, lactation, infancy, childhood, and adolescence, and for athletes.» (5).

Kostrådene utgitt av Nasjonalt råd for ernæring i 2011 anbefaler, i kostråd nummer én, et kosthold som hovedsakelig er plantebasert
(6). De nyeste nordiske næringsstoffanbefalingene, NNR 2012, sier at et plantebasert kosthold er assosiert med lavere risiko for flere sykdommer (7). Forskning har vist at vegetarianere har lavere risiko for å dø av hjerteinfarkt, lavere risiko for diabetes, fedme og visse typer kreft. Vegetarianere har i gjennomsnitt lavere blodtrykk, vekt og kolesterolverdier $(5,6)$. Ved diabetes type to anbefaler Helsedirektoratet at grønnsaker og belgvekster bør ha en sentral plass i kosten (8). Også Landsforeningen for hjerte- og lungesyke (9) og American College of Cardiology anbefaler et hovedsakelig plantebasert kosthold (10).

Vi som leger har et ansvar for å opplyse pasienter og befolkningen generelt om at et riktig sammensatt plantebasert kosthold er fullverdig og innebærer store helsefordeler.

\section{Tetyana Kalchenko}

tetk2003@yahoo.no

Lars Thore Fadnes

Tetyana Kalchenko (f. 1974) er lege og medlem i foreningen Helsepersonell for plantebasert kosthold.

Ingen oppgitte interessekonflikter.

Lars Thore Fadnes (f. 1982) er lege og helseforsker.

Ingen oppgitte interessekonflikter.

\section{Litteratur}

1. Kvåle G. Klimakamp er helsearbeid. Tidsskr Nor Legeforen 2014: 134: 1582-4.

2. FAO. 2006. Livestock's long shadow. www.fao.org/docrep/010/a0701e/ a0701e00.HTM [1.9.2014)

3) Miljødirektoratet. Forslag til handlingsplan for norske utslipp av kortlevde klimadrivere. Rapport M-89/2013. www.miljodirektoratet.no/no/Publikasjoner/ 2013/Desember-2013/Forslag-til-handlingsplan-for-norske-utslipp-avkortlevde-klimadrivere/ (22.9.2014)

4. Mekonnen MM, Hoekstra AY. The green blue and grey water footprint of farm animals and animal products. Vol 1. Main Report. Value of water. Research report series No. 48. UNESCO IHE Institute for water education. 2010.

5. Craig WJ, Mangels AR. Position of the American Dietetic Association: vegetarian diets. J Am Diet Assoc 2009; 109: 1266-82

6. Nasjonalt råd for ernæring. Kostråd for å fremme folkehelsen og forebygge kroniske sykdommer, 2011. http://helsedirektoratet.no/publikasjoner/kostradfor-a-fremme-folkehelsen-og-forebygge-kroniske-sykdommer/Publikasjoner/ kostrad-for-a-fremme-folkehelsen-2011.pdf (1.9.2014)

7. Nordisk ministerråd, NNR-2012. Nordiske næringsstoffsanbefalinger www.norden.org/sv/tema/nordic-nutrition-recommendation/ (1.9.2014)

8. Helsedirektoratet. Behandling av diabetes. http://helsenorge.no/ Sykdomogbehandling/Sider/diabeteskosthold/Vekt.aspx (1.9.2014)

9. LHL. Spør eksperten. Plantebasert kosthold. www.lhl.no/spor-eksperten/ sporsmal/Plantebasert-kosthold/ (1.9.2014)

10. William KA. Vegan diet, healthy heart? American College of Cardiology in Touch Blog. http://blog.cardiosource.org/post/vegan-diet-healthy-heart/ ?WT.mc id=cvnewsdig [1.9.2014]

\section{G. Kvåle svarer:}

Jeg takker Kalchenko og Fadnes for en viktig kommentar til artikkelen Klimakamp er helsearbeid (1). Som det påpekes, kan leger gjennom kostholdsråd til pasienter og befolkingen generelt bidra både til bedre helse og til reduserte klimagassutslipp. I tillegg mener jeg det bør legges opp til en prispolitikk som avgiftsbelegger kjøtt og annet helse- og klimaskadelig kosthold, slik at et kjøttbasert kosthold blir dyrere og frukt, grønnsaker og annet plantebasert kosthold relativt billigere.

Regjeringen nedsatte i august en grønn skattekommisjon som skal vurdere hvordan en grønn skatteomlegging kan bidra til bedre ressursutnyttelse og til å oppfylle målene i klimaforliket (2). I denne sammenheng bør avgifter på klimaskadelig kosthold og landbruksproduksjon samordnes med avgifter som fremmer helse. Kostvaner er vanskelig å vende. Det er derfor nødvendig at prisforskjellene mellom klima- og helsemessig gunstig kosthold og alternativet blir så store at dette virker til en rask omlegging. Dette må komme i tillegg til folkeopplysning som begrunner hvorfor en slik omlegging er nødvendig.

Regjeringens målsetting er å kutte 8 millioner tonn $\mathrm{CO} 2$ innen 2020 (3). Målet blir ikke annet enn et fromt ønske så lenge ikke 
Erna Solberg og andre regjeringskolleger satser på en klimavennlig politikk i alle sektorer. Regjeringen legger tvert imot opp til et mer energi-intensivt landbruk, en veisatsing som forutsetter massiv økning i biltrafikken, og utbygning av Gardermoen og Flesland, som forutsetter sterk økning i flytrafikken. Det er ikke engang regnet på hvilket klimafotavtrykk disse satsingene vil medføre, mens det regnes i detalj på klimafotavtrykket for utbygging av tog og andre miljøvennlige tiltak.

En klimalov etter mønster fra Storbritannia kunne fått stor betydning som en ramme for en helhetlig klimapolitikk (4). Men selv om fem partier på Stortinget går inn for dette, har ikke Høyre-Frpregjeringen så langt vist vilje til annet enn å utrede hensiktsmessigheten av en slik lov (5). Dette er symptomatisk for norsk klimapolitikk. Politikerne sier at det haster med å redusere klimagassutslippene, men Regjeringen fører i praksis en «business as usual»-politikk som ikke vil føre til nødvendig nedgang.

\section{Gunnar Kvåle}

gunnar.kvale@cih.uib.no

Gunnar Kvåle (f. 1942) er professor emeritus ved Senter for internasjonal helse, Universitetet i Bergen.

Ingen oppgitte interessekonflikter.

\section{Litteratur}

1. Kvåle G. Klimakamp er helsearbeid. Tidsskr Nor Legeforen 2014: 134: 1582-4.

2. Finansdepartementet. Ny grønn skattekommisjon. Pressemelding 27.6.2014.

www.regjeringen.no/nb/dep/fin/pressesenter/pressemeldinger/2014/

Ny-gronn-skattekommisjon.html?id=764700 (18.9.2014)
3. Miljødirektoratet. Faglig grunnlag for videreutvikling av den nasjonale og internasjonale klimapolitikken. Klimatiltak mot 2020 og plan for videre arbeid. Rapport M-133/2014. www.miljodirektoratet.no/no/Publikasjoner/2014/Mars-20141/ Faglig-grunnlag-for-videreutvikling-av-den-nasjonale-og-internasjonale-

klimapolitikken---Klimatiltak-mot-2020-og-plan-for-videre-arbeid/ [22.9.2014)

4. World Wildlife Fund (WWF) - Norge. En norsk klimalov, WWF-Norge, 2011

5. Halsør M, Aune Nilsen A. Fem partier krever egen klimalov. Nrk 08.4.2014. www.nrk.no/norge/fem-partier-krever-klimalov-1.11657664 19.9.2014

\section{RETTELSE}

Re: Profesjonalitet kommer ikke av seg selv

Eivind Lied

Tidsskr Nor Legeforen 2014; 134: 1634

| Tidsskriftet nr. 17/2014 side 1634 skal riktig fødselsår på forfatteren være 1988

Vi beklager feilen, den er rettet $i$ nettutgaven. 